\title{
Pharmacology of Desire: Drive-based \\ Capitalism and Libidinal Dis-economy
}

\section{Bernard Stiegler}

\begin{abstract}
The concept of desire is the key to understanding the relation between economics and psychoanalysis, that is, between social and psychic investment, or between productive and libidinal economies. Today, the system organising the relation between these two economies is less a matter of biopower than of 'psychopower', technologies and industries developed in order to control the behaviour of consumers. But this system interferes with the intergenerational circuits on which desire has hitherto always been based. Consequently, the system is now encountering certain limits, threatening the collapse of the system itself, and requiring a new economic understanding, itself dependent on a new theoretical foundation for understanding desire in general.
\end{abstract}

Keywords psychoanalysis, economics, consumerism, Sigmund Freud, Herbert Marcuse, Donald Winnicott

There is a figure who for a long time remained almost entirely unknown, in particular within the world of psychoanalysis, but who played a major role in establishing the economic model that currently seems on the way to collapsing before our very eyes: Edward Bernays, who happened also to be Freud's double nephew. Bernays forged the basic concepts of what he called 'public relations', the earliest version of what would later become marketing. He instituted managerial and commercial practices founded upon readings of his uncle's work, and he proposed to totally reconfigure American industrial policy as a libidinal economy.

The libidinal economy of the twentieth century has been progressively but completely transformed by marketing, which constitutes what I call a psychopower, and which is as such related to what Foucault named 'biopower'. Biopower controls populations of producers through the technologies of disciplinary power. Psychopower controls the individual and collective behaviour of consumers by channelling their libidinal energy toward commodities - by provoking the investment of desire in the object of consumption it becomes possible to derive profits from industrial investment in the apparatus of production.

The thesis I am defending here seems at first glance to be quite close to that of Herbert Marcuse. It is, however, very different, and in what follows I hope to clarify this difference. I propose on the one hand that there is in principle a historicity of the unconscious - this was also Jacques Lacan's argument, although he does not thematise it as such (I will return to this question). But 
on the other hand I propose that this historicity takes the form of the relations between the economy of subsistence, that is, of needs, and the economy of existence(s), that is, of desires, desires that themselves equally presuppose an economy of what I call 'consistences,' that is, of objects of idealisation in all its forms (infantile, amorous, artistic, scientific, philosophical, political, and religious, among others).

The planetary crisis to which we are subject is the collapse of the consumerist arrangement between subsistence and existence - a collapse due to the liquidation of consistences that has taken place, that is, the liquidation of idealisation and sublimation in all their forms (and it is on this point that my argument resembles that of Marcuse, in particular insofar as he makes use of the concepts of de-sublimation and the automatic superego). With the appearance of psychotechnologies, the first critics of which were Walter Benjamin and the Frankfurt school, the historicity of the unconscious made possible a libidinal dis-economy, that is, a destruction of the libido as the power of binding the drives - that power of binding that we must understand by relating it to the binding power of Kant's transcendental imagination thereby opening the question of what I call here the pharmacology of desire (referring here to the Greek, Platonic, and Derridean understandings of the pharmakon as both poison and cure).

In the consumerist economy, the drives are diverted from their aims and toward artificial needs - needs that fail to constitute any desires. Adorno and Horkheimer already had a sense of this when they argued that the Hollywood system of projection short-circuits imagination. I have, however, tried to show in a work yet to appear that their analysis neglects the fact that the imagination is always constituted through transitional artefacts and that it is not the technical exteriorisation of the imagination that causes the short-circuit, but rather the cultural hegemony that psychopower exercises on what must be understood as a pharmakon.

Fantasies in general proceed from the polymorphism intrinsic to the libido, but in the case of consumerist fantasy, the diversion fails to lead to any libido, since it on the contrary rests on de-sublimation and de-idealisation. The object of consumption, as soon as it is invested, must be dis-invested: consumerism is an economy of disposability, that is, of infidelity. Consumers must not become attached to their objects: they must consume, precisely, by detaching themselves from them, by destroying them and by disposing of them in order to follow the diversion of the energy of their drives toward the ever-newer objects propelled towards them by industrial innovation.

I have tried to show in For a New Critique of Political Economy ${ }^{1}$ that this drivebased (rather than desire-based) organisation of consumption has its counterpart on the side of capitalist investment, in the form of the tendency of investment to become speculative, that is, essentially unfaithful: it tends structurally toward disinvestment. Hedge funds and leveraged buyouts (LBOs) are such organisations of dis-investment - and are essential factors in our economic ruination.

1. Bernard Stiegler, For a New Critique of Political Economy, Cambridge, Polity, 2010 . 
2. Sigmund Freud, 'Civilization and Its Discontents', The Standard Edition of the Complete Psychological Works of Sigmund Freud, vol. 21, London, Hogarth Press, 1953-74, p90.

3. Of which I have tried to outline a theory, as the genealogy of the sensible, in De la misère symbolique 2. La catastrophè du sensible, Paris, Galilée, 2005.

4. Stiegler, Ce qui fait que la vie vaut la peine d'être vecue: De la pharmacologie, Paris, Flammarion, 2010, p31-32.
The historicity of the unconscious and of the libidinal economy in general results from the 'organic perfecting' (or 'organic improvement') that Freud describes in Civilisation and Its Discontents: '[M]an is perfecting his own organs'.

I have tried to show, in Ce qui fait que la vie vaut la peine d'être vecue: De la pharmacologie, that this is a pharmacological situation:

In this 'malaise' of culture and civilisation, technics (prostheticity) plays an essential role, because it is eminently pharmacological, in particular as the system of artificial organs that it forms in the industrial age ... In the course of this 'perfecting' [or this improvement], ${ }^{3}$ technics comes to ceaselessly compensate for a default of being (of which Valéry also speaks) by provoking each time a new default - always greater, always more complex and always less manageable than the one that preceded it. This constant disadjustment induces frustrations, narcissistic wounds, and melancholy. ${ }^{4}$

This pharmacology, that must be studied alongside the work of Georges Canguilhem, passes through a series of organic de-functionalisations and refunctionalisations, which must be thought in terms of a general organology, and which would then constitute what I have called a 'genealogy of the sensible'.

Philosophy begins by repressing the question of technics, but technics is also the repressed heart of the question of repression [refoulement] understood in the psychoanalytic sense of the word. Sublimation presupposes repression. This is a matter of the expressive elevation constitutive of the libido insofar as it is characterised by its capacity to detach itself from its sexual objects, as much as it is a matter of repression [la répression, which has a greater sense of suppression or of repression in a social or political sense] and the regressive processes in which it results, such as the domination of a symbolic system. It is the possibility of elevation as much as it is the possibility of falling, in that it proceeds from a repression that must be analysed on three economic planes, linked to the three levels constitutive of general organology: political economy as division of labour and organisation of production; symbolic economy, which is linked to the preceding stage as the economy of gift and countergift; and libidinal economy, as the drive-based origin and energetic source of the two preceding stages. These three economic levels form the three levels of organological composition.

There is no libido without aesthetics, and this is why Lacan speaks of the 'erogenous function of beauty'. But the libidinal aesthetic is in an essential way pros-thesic [une prothesthésie]. Prostheticity is the foundation of human aesthetics as that pros-thesics that can only take shape [prendre corps, come into being, materialise] with the conquest of the upright stance, of erect posture, the inaugural moment of a process through which the hand, abandoning its locomotive function, invents a fabricative function. The de-functionalisation 
of the paw, which thereby becomes the hand or the foot, is the very opening of technicity, and constitutes a re-functionalisation (a functional re-equilibration or readjustment, as André Leroi-Gourhan says): the hand is then the producer of signs, objects, artefacts, prostheses, and works. And the foot starts to dance. This working hand opens a world [cette main ouvrière ouvre un monde].

The organological history of aesthetics consists in a succession of functional exteriorisations and correlative de-functionalisations, that also produce functional reassignments affecting the sense organs, on the basis of which pros-thesicity is constituted as a new power of repetition.

These reassignments channel the energies of the 'libidinal economy' in which this results, energies that are created through this de-functionalisation. Because if it is true that the libido is not the sexual drive, but rather desire insofar as it is capable of diverting its energy toward non-sexual objects, then this would only be possible to the extent that the de-functionalisation at the base of what Freud calls organic repression permits the detachability [amovibilité] of technical objects, itself the condition of a process of adoption. And it is only on the basis of such organological de-functionalisation and re-functionalisation, ceaselessly redefining the functional systems that support all 'aesthetics', that the tekhnai can be produced as the ars and arts necessary for a 'sharing out of the sensible' ['partage du sensible'] - the arts being nothing other than a dimension of the aesthetic in which such a sharing out is produced, which is also a process of sublimation in the widest sense.

This constant functional re-equilibration at the limit of dis-equilibrium, in which the history of the psychic and collective individuation process consists, unfurls the consequences of the process of organic repression at the origin of repression in general. According to Freud, this repression begins through a defunctionalisation of the olfactory sense correlated to the conquest of the upright stance, that is, to the thought of elevation implied when Leroi-Gourhan, in a way that is very close to Nietzsche, writes that 'everything begins with the feet'. The prosthetic dimension, which constitutes human sensibility or perceptibility insofar as it is noetic, characterises the becoming of sexual difference, something that is already clearly at work in animality. But the prosthesis, as support of fetishisation and the surface of projection constitutive of narcissism, completely reconfigures this, inscribing it within the necessity of a judgment - that is, in the possibility of an aesthetic preference, about which it may be asked whether it does not emerge from the dietary practices of the great apes, the appearance of such preference having already been examined by Darwin in relation to the sexual behaviour of birds, a judgment and a preference that from his own perspective Lacan characterises as the 'formative and erogenous' function of beauty.

Now, it is on this pros-thesic foundation that a capitalist libidinal economy can be constituted, which will draw upon the culture industries and the psychotechnologies in which these industries consist.

The functional transformation of the sense of smell, which signifies or inaugurates organic repression, is for Freud a consequence of the upright 
5. Freud,

'Civilization and Its Discontents', op. cit., p99. stance. This conquest of the upright stance also clearly has a close relation to that of the weapon, of arms, since this is the concrete expression, in the form of the tool, of what this conquest made possible, by liberating the hand from its relation to locomotion, and it is therefore clearly also related to fabrication, and to practice, and such that it thus also leads, and simultaneously, to the defunctionalisation in a sense of the profit deriving from libidinal reinvestment. Because all this in its totality constitutes the question of fetishism, that is, of hallucination, through which the sensible becomes 'sensational' or, when sublimated, becomes the support of noetic expression.

Nevertheless, these organological displacements are thought by Freud only on a physiological plane, without any consideration being given to artefacts, in spite of the important place they hold in the interpretation of dreams. They are explicitly re-examined in 1929, thirty four years after the letter to Fliess on smell, under the name of organic repression, and expressly analysed as the condition of sublimation:

[W]ith the assumption of an erect posture by man and with the depreciation of his sense of smell, it was not only his anal erotism which threatened to fall victim to organic repression, but the whole of his sexuality; so that since this, the sexual function has been accompanied by a repugnance which cannot further be accounted for, and which prevents its complete satisfaction and forces it away from the sexual aim into sublimations and libidinal displacements. ${ }^{5}$

There is for Freud certainly an organology of sublimation, and it consists in an organic displacement: this is at once a de-functionalisation and a refunctionalisation of the organs of smell and sight, inscribed in what LeroiGourhan would call a new functional equilibrium, in which a reinforcement of the visibility of the genital organs operates to the detriment of the olfactory sense, and this organic repression is also a symbolic repression, in such a way that modesty or shame is practically induced by this process of elevation in which the conquest of the upright stance consists.

Now, the elevation that is the upright stance led the way, according to Freud, to modesty or shame, to la verguenza [in Spanish], that is, to what the Greeks called aidos, and to the 'commencement of the ineluctable process of civilisation', the sexual foundation of which is organological in this sense, that is, tied to the becoming of the genital organ and to the role of the organ of sight induced by the de-functionalisation of the olfactory organ. And all of this, if one relates it to the narrative told by Protagoras, inspired by Hesiod, Aeschylus, and the whole of Greek mythology, is conditioned by the technical and prosthetic becoming of human being.

Now, this is what was eventually confirmed by palaeo-anthropology in the second half of the twentieth century. The conquest of the upright stance is not tied to the fact that man 'resolved to walk upright', as Freud dared to 
put it, but to the establishment of a new functional equilibrium, induced through a 'neotenisation' that is of great interest to Lacan, and of which the reality is immediately and at once the verticalisation of the human body and its prostheticisation, that is, the abandonment of the locomotive function of the hand to the benefit of a new fabricative function. This new function amounts to the appearance of work, in the form of an economy of pleasure in the construction of reality, that is, in its invention, a diversion of libidinal energy from sexual goals, and as such the birth of sublimation both as the pleasure principle and beyond this principle.

In spite of all he says about organic improvement or perfecting, Freud never thinks the role of artefacts in the constitution of memory or the unconscious (this is particularly striking in Moses and Monotheism, but was already clear in Totem and Taboo). On the other hand, the historicity of figures of desire, that is, of the unconscious, seems very close to being enunciated by Lacan insofar as he reflects on the place of sublimation in courtly love and in the literary structure of the unconscious:

Although it has completely disappeared nowadays from the sociological sphere, courtly love has nevertheless left traces in an unconscious that has no need to be called 'collective', in a traditional unconscious that is sustained by a whole literature, a whole imagery, that we continue to inhabit as far as our relations with women are concerned. ${ }^{6}$

And in his Address to Catholics, he expressly puts sublimation into a relation with technics:

6. Jacques Lacan,

The Ethics of

Psychoanalysis,

London and New

York, Routledge, $1992, \mathrm{p} 112$.

We know what is in it of earth and sky, the one and the other being empty of God, and the question is to know what we make appear in the disjunctions that constitute our techniques ... The Freudian Trieb, the first and the most enigmatic notion of his theory, ran into a stumbling block, causing a great scandal among his disciples, in the form and formula of the death drive. This is, nevertheless, the response of the Thing when we wish to know nothing about it. Nor does it know anything of us. But is there not also a form of sublimation around which human being, time and again, revolves? Is this libido, of which Freud informs us that no force within man can sublimate it, not the ultimate fruit of that sublimation through which modern man responds to his solitude?

The premier question that the capitalist industrial economy poses for the theory of the unconscious, and for the theory that desire is founded upon repression, is the question of the technicity of this desire, that is, of its historicity such that, given the fact of its essential exteriority, an exteriority that we must 
relate to what Winnicott called the transitional object and transitional space, the libidinal economy can be destroyed by its industrial exploitation through the use of the psychotechnologies of psychopower. This economy of the artefact (and of fantasy) is also a pharmacology. The artefact is at once the condition of the formation of desire as such, and the possibility of its systemic regression, if not its total destruction. This systemic regression is linked to the organisation of systemic infidelity necessitated by innovation, by that innovation theorised by Joseph Schumpeter in 1911 without him perceiving any of its consequences - no more than did Keynes.

If it is the case, however, that the juvenile psychic apparatus is now prematurely and systemically affected by contemporary pharmacological toxicity, then the question must be posed of a libidinal dis-economy. The clinical and sociopathological as well as psychopathological problem that the capitalist libidinal economy poses is that of its self-destructive character, that is, its domination by the death drive.

Maintaining such a viewpoint means reaffirming the question of desire. As libidinal energy, desire is produced by that apparatus that transforms the drives into investments in objects, via binding systems that are at once super-egoic and sublimatory (and these cannot be separated: there is no superego without figures with whom to identify, without those identificatory figures produced by sublimation - the question being to know whether the reverse is also true).

This apparatus operates with what I have analysed (in Technics and Time, 3: Cinematic Time and the Question of Malaise) as retentional systems, that is, systems for the production of selection criteria for primary and secondary retention, which together form a psychic apparatus. These are super-egoic and sublimatory apparatuses, and as such found their criteria on the long circuits of a transindividuation process that ties the generations together, a process that finds itself short-circuited by the psychotechnologies submitted to the hegemony of psychopower, and which thus results in short-circuits in transindividuation.

Such short-circuits engender regressive identification processes of the type described by Freud in his Massenpsychologie [Group Psychology and the Analysis of the $E g o]$. But they also massively provoke what I have called generalised proletarianisation - that is, a massive loss of savoir-vivre and a process of systemic disapprenticeship (of un-learning).

Long circuits of desire are created through transindividuation, and thus transindividuation, like these circuits themselves, has an intergenerational structure. The scene of transindividuation forming such circuits is par excellence the Socratic dialogue, in which the speakers share a common preindividual fund charged with potential, that is, with trauma, with protentions in suspense, with repressed elements, with symbolic charges of all kinds. It is these charges that regularly oblige Socrates to convoke myths and associated mystagogies, of which the priestess Diotima is one figure.

Dialogical activation liberates these charges, and this is what is described by 
the myth of the winged soul in Phaedrus. When dialogical transindividuation produces a long circuit or, rather, pursues or follows a long circuit, it results in what Plato called anamnesis. Anamnesis relates the dialogue and its speakers to the origin of their discursive object, that is, their significant object - and as an extra-ordinary object, that is, one that is ideal.

Referring here to the Platonic dialogue is not meant to suggest that this is the essential form in which transindividuation is produced (and most of the time it is on the contrary produced in completely other forms and through completely other practices), yet it remains the case that what philosophy works upon, as the foundation of knowledge at the origin of the West, is this structure that leads to the constitution of the law as the law-bound character [legalité] of transindividuation processes - since what is at issue in all philosophy, and in particular in that nascent philosophy concerning us here, is the formation of a political lawfulness, or a political legality, in harmony with the lawfulness of logos in all its forms.

Trans-individuation presupposes an individuation of each speaker, that is, a trans-formation that creates a circuit through the one who is trans-formed precisely by having the circuit pass through them, eventually to the point of opposing oneself to circuits that pass through other interlocutors. These long circuits return us to our original questions concerning the unconscious, that is, in the end, to the default of origin - what Freud and Lacan called das Ding.

This default is also what constitutes desire (eros) as penia, that is, default - as that which has a lack, or a need, or a defect [comme ce qui fait défaut], and as I have tried to show elsewhere, this default is that which becomes what is necessary [ce qui devient ce qu'il faut] in desire itself, and which causes the establishment of desire just as much as it causes its collapse (because it is pharmacological), ever since the prostheticisation of the living, that is, at the same time, ever since the appearance of this weapon, these arms, that make it possible, according to Totem and Taboo, for the sons to kill the father of the horde. Freud, indeed, asks himself what it is that pushes the sons into this crime, and he hypothesises that the answer must be 'the appearance of a new weapon', without himself understanding that it is the appearance of the weapon insofar as it is a prosthesis, an artefact and a pharmakon that opens this process through which what eventually emerges is the law.

When Diotima says to Socrates in Symposium that philosophy is desire, this means that philosophy idealises its objects as desire, since in all its forms desire is the process of such idealisations. Now, this consists in infinitising the objects of these investments, and through that in projecting them onto circuits that are potentially infinitely long - faith being constituted on this infinite potentiality. Such infinitisations, which become sublimations, form the basis of knowledge(s) of all kinds. Such knowledge(s) are in a broad sense dialogical, according to a sense that passes through the work of Bakhtin: in the sense that those who put knowledge(s) to work participate in their formation through the very fact of putting them to work or utilising them, and individuate them, 
just as occurs in the Platonic dialogical scene.

This is the way that associated milieus form, that is, transitional milieus through which those who are bound by transitional objects and who are constituted through this very binding (which is that of desire) participate in the individuation of this milieu itself by co-individuating and trans-individuating themselves - that is, by projecting themselves onto the intergenerational plane.

The long circuits of transindividuation that constitute long circuits of desire can also pass through circuits that are not short-circuits, but that are circuits that may nevertheless be short - such as, for example, in humour, laughter, Witz, comedy, poetry, puns, and art in general. But these circuits are short only because they are very fast - they may in fact be very long but the distance is covered very rapidly, so that, in jumping across the barriers of the psychic apparatus, they in some way manage to tickle souls.

It is in this way that the id [le ça, literally, the 'it'] can cause laughter: like a ball within long circuits that can with great speed fly across great distances in the games of the $i d$. These games would also be those of Winnicott, and thus tie the $i d$ to the transitional object as the pharmakon of play. It is in this way that the $i d$ ties together the generations, in the first place through that primordial pharmakon that is the transitional object.

Now, the consumerist economy, by posing in principle the intrinsic disposability of all objects, short-circuits primary identification and more generally the relation of care. The consumerist economy constitutes as such an enormous process of dis-apprenticeship and of the destruction of associated and dialogical milieus - since the symbolic, submitted to the functional opposition between the industrial producers of symbols and the consumers of this production, is, through this very process, de-symbolised.

Consumers are de-symbolised because they no longer participate in any way in the emergence of their transitional milieu - and this milieu becomes through this very fact intrinsically toxic. It is in this way that dissociated milieus are constituted, that is, milieus within which psychic individuals are dis-individuated, and through which the libidinal economy becomes a dis-economy, that is, a systematic and systemic process of liberating the drives from whence they came. The name taken by this process, toward the end of the 1970s, in both the United Kingdom and the United States, is the 'conservative revolution', bringing with it neo-liberalism.

Psychopower functionalises games that become systems for capturing and harnessing attention. Beyond that, psychotechnologies aim to incite and control secondary identification processes, or, if not these processes themselves, then at least their symbolic content, which is in this way de-symbolised. This results in a standardisation of secondary retentions, that is, of the mnesic traces that constitute the criteria put to work by each individual within that selective operation that always accompanies what Husserl calls primary retention (that is, in the weave of the flow or flux of perception). This thus also implies that 
what results is psychic dis-individuation and a de-singularisation of experience or, in other words, a short-circuit of experience itself.

This is precisely what Patrick Le Lay, president of the French television network TF 1, infamously called the production of 'available brain time', which is then 'sold to Coca Cola'.

Libidinal ecology (that is, libidinal economy insofar as it always presupposes an intrinsically pharmacological transitional milieu) is thus ruined by the psychotechnologies implemented by psychopower exclusively in the service of the drives - and it results in an addictogenic society imposed through a drive-based capitalism in which the addictive and drive-based behaviour of consumers forms a system with that of speculators, whose behaviour is just as drive-based, that is, ultra-short-termist.

This de-symbolisation that destroys all credit and therefore all law provokes generalised dis-investment. The fundamental economic question - that is, the question that links the economy of subsistence and the economy of existence(s) (by projecting imaginary consistences of idealisations) - is that of investment: investment understood firstly as libido, binding in time the diverse energies of the drives at the core of a subject but also at the core of an intergenerational game; and investment understood secondly as the economic space of capitalist investment through which an entrepreneurial class can be maintained through a system of protentions, that is, through the social liaison or binding of more or less convergent desires. Such at least is what I have argued in For a New Critique of Political Economy.

As a system of protentions, capital is a specific pharmakon regime that founds desire. Desire is protention - an infinite investment in its object. What takes place with the new pharmacology encountered by Luther in the form of the printing press is the advent of capitalism as it was described by Weber, that is, a new modality of investment itself tied to paper money - to that very particular product of the printing press that is the banknote, and notably the dollar bill, on which is inscribed not 'In God we believe', but rather, 'In God we trust'.

Money is pharmacologique en diable, as one says in French, diabolically pharmacological, and it is the very figure of the devil in pre-Lutheran Christianity. Now, before anything else money is both a tertiary retention and a tertiary protention. This is so insofar as money permits the development of capitalism as a protentional system projecting desires and investments. But money is a pharmakon precisely because, as much as it is a system projecting desires, it is also a system of calculation and accounting enabling the transformation of belief into trust, reducing everything to calculability and ineluctably ruining trust itself to the extent that desublimation, which is the destruction of those objects of desire that are also projectors of infinity, is therefore a finitisation, which is then translated into a dis-investment that becomes speculation.

This system, tending toward that de-symbolisation described by Weber 
7. Stiegler, Mécréance et discrédit 3: L'esprit perdu du capitalisme, Paris, Galilée, 2006. essentially as secularisation and disenchantment, has today reached a stage that must be apprehended as extreme disenchantment - an extreme limit in which three limits of capitalism combine and potentise one another, that is, reinforce each other's effects, in the same way that combining drugs can be dangerously potentising, as medication labels frequently warn. These limits of capitalism are: (1) the tendency of the profit rate to fall; (2) the tendency of libidinal energy to fall; and (3) the spread of negative externalities (engendered by generalised systemic infidelity and disposability), thereby destroying the elementary conditions for the functioning of an industrial system that exploits and transforms both matter and behaviour.

This extreme limit of consumerist capitalism - the toxicity of which is in every sense explosive and which has been revealed to be structurally addictive - is encountered at the very moment a new pharmacology is being put in place. Space limitations prevent a detailed discussion of this, but it must at least be noted that this encounter also opens the possibility of a way out of the consumerist industrial model, and the possibility of reconstituting associated milieus and a rich transitional and symbolic life through novel rearrangements of the economy of subsistence and the economy of existence(s).

To think all this with psychoanalysis, however, must also be to profoundly rethink psychoanalysis itself, that is, in its relation to the default of origin that is the prosthesis, the origin of that organic perfecting of which capitalism would be the literally stupefying period, a period leading, as an immense operation of dis-apprenticeship and generalised proletarianisation, to what must be called not only systemic stupidity, that is, a state of spasmodic mental tetany that produces a paralysing stupor, but really to une bêtise systémique, to a systemic beastliness (where betise, the kind of stupidity we are translating here as beastly, cannot be reduced to the kind of stupidity that is merely stupefied), that is, to a drive-based regression founded on the destruction of libidinal energy itself insofar as it binds the drives through the intermediary of pharmaka that weave the symbolic, from Winnicott's transitional and pre-verbal object to the signifer that founds the thought of Lacan.

What, then, of my divergence from Marcuse's argument? It is not possible to give a detailed explanation here, and a fuller account can be found in Mécréance et discrédit 3: L'esprit perdu du capitalisme. ${ }^{7}$ In just a few words, however, and by way of conclusion, let us say that Marcuse's central thesis is that the reality principle has become, in the age of industrial capitalism, a performance principle in the service of what he calls 'surplus-repression'. And he proposes a critique of the Freudian theory of the libido to the extent that it would consist in naturalising a state of affairs that is in fact historical, and therefore contingent. Marcuse thus proposes modifying the Freudian perspective in the service of a struggle to 'liberate the instincts', a change in theoretical perspective consisting first of all in distinguishing two planes of the reality principle - distinguishing the structural plane, which is as such a kind of 'nature of desire', from the historical plane, that is, a plane current to the particular age. And as for this historical 
plane, Marcuse's thesis is that, in the industrial age, it is the performance principle that represents the configuration of the reality principle proper to this age.

This distinction is interesting because its point of departure is the principle that psychoanalytic categories are formalised within a processual historicity, a historicity within which forces take shape capable of formalising such categories. It is clearly not possible, however, to locate and 'dis-engage' a structural plane that would not have been always already historical, that is, historically or proto-historically or pre-historically engaged [gagé], that is, artefactual, and would have been so to the extent that the artefact is precisely the operator of the processuality and the historicisation of its categories, and which engages desire precisely as a process of individuation - but this is exactly what escapes Marcuse. If the artefact is the operator of the process, that is, the condition of the process, then this means that there would be no way of isolating a pre-processual basis of that process. And this means that the 'structural' is elementarily 'historical' and as such 'accidental', and is neither guided nor contained by any ontology that would make it possible to define the constitutive elements of the process. The elements are always already supplements: elementarity is an elemental supplementarity.

What I call here the process of the formation of psychoanalytic categories, that is, of elements always already become supplements (always already held within a phantasmatic and fantastic mechanism, that is, a fictioning of the real, and as technical invention) is the process of psychic, collective and technical (that is, artefactual) individuation, and within such a process, it is less the elements that count so much as their relations. If there are elements that maintain their forms, or rather their metastable rather than stable forms, then this can only be true insofar as forces, constituted by relations, that is, by what are at least coupled pairs, may seem to be opposed but are, in reality, in the course of com-posing - and a composition that cannot, contrary to Cartesian method, be de-composed into its mere elements without being destroyed through the very fact of this decomposition. And the joint becoming of these relations, within such a three-stranded individuation process, raises the question of a genealogy, itself conceived from out of an organology.

The general organology outlined at the beginning of this article is the theoretical framework of the genealogy that would give an account of this processuality.

Keynote lecture delivered to the Psychoanalysis, Money and the Economy Conference, Freud Museum and Birkbeck College, 3 July 2010

Translated by Daniel Ross 